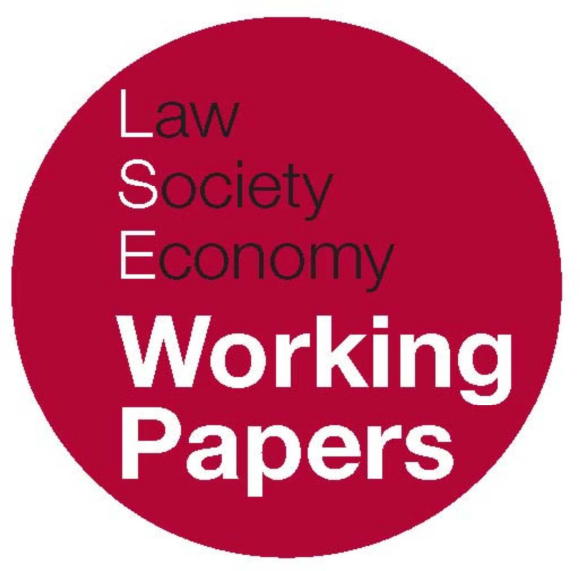

\title{
Faking Democracy with Prisoners' Voting \\ Rights
}

\author{
Peter Ramsay
}

LSE Law, Society and Economy Working Papers 7/2013

London School of Economics and Political Science

Law Department

This paper can be downloaded without charge from LSE Law, Society and Economy Working Papers at: www.lse.ac.uk/collections/law/wps/wps.htm and the Social Sciences Research Network electronic library at: http://ssrn.com/abstract $=2214813$.

(C) Peter Ramsay. Users may download and/or print one copy to facilitate their private study or for non-commercial research. Users may not engage in further distribution of this material or use it for any profit-making activities or any other form of commercial gain. 


\title{
Faking Democracy with Prisoners’ Voting Rights
}

\author{
Peter Ramsay
}

\begin{abstract}
In the dispute between Strasbourg and Westminster over prisoners' voting rights, the arguments of both sides help to consolidate the emerging 'post-democratic' political regime in Europe. The UK government's position in Hirst $v$ UK, and the judgments of the Strasbourg courts in Hirst, Frodl v Austria and Scoppola v Italy, all assume that democracy is no more than a matter of voter-consumers choosing between competing alternatives in the political market place. This minimalist conception of democracy also underlies the argument that enfranchising convicted prisoners will contribute to their rehabilitation. If, by contrast, democracy is thought of as a regime that seeks to achieve the collective self-government of the people, then one of its principles is that only those who enjoy civil liberties and formal independence of the executive can be self-governing citizens. Enfranchising prisoners subverts that democratic principle.
\end{abstract}

* Senior Lecturer in Law, London School of Economics and Political Science. I am grateful to Suke Wolton for her comments and to Kai Möller for his advice on aspects of the ECHR. The usual disclaimer applies. 


\section{INTRODUCTION}

Section 3 of the Representation of the People Act 1983 prohibits convicted prisoners from voting in national or local elections until after their release. In Hirst $v U K$ the Grand Chamber of the European Court of Human Rights ruled that this ban violated prisoners' right to vote, a right protected by Article 3 of Protocol 1 ECHR. This has led to a prolonged stand-off between the UK government and parliament, on the one hand, and the Strasbourg court on the other - a stand-off that is still going on at the time of writing. In this, as in so many questions relating to criminal justice, a large majority of expert academic and legal opinion - in backing Strasbourg's demand that the ban be reformed - finds itself at odds with both parliament and the government. ${ }^{1}$

Against the grain of the academic literature, I will argue here that the Strasbourg court is wrong and that the UK's ban is necessary in a democratic society. I will not, however, adopt the retributive argument that the UK government has made in defence of the ban. On the contrary, I will develop the democratic argument in favour of the ban by first explaining why the UK government's position is an undemocratic one, and why it failed to convince the Grand Chamber. Then I will argue that the Strasbourg court's judgments reveal assumptions that, from the democratic point of view, are no better than the government's argument. I will conclude that the widespread support for the Hirst judgment among penal reformers and human rights advocates constitutes a greater danger to democracy than the government's arguments in favour of the ban.

The essence of my argument is that both the UK government and the Strasbourg court imagine democratic citizenship to be no more than a question of choosing between alternative political representatives. The Court's position, in particular, implicitly discounts the right of citizens in a democracy to influence both the choices that other citizens make and the political content of the available choices, and their right to enjoy this influence independently of executive interference. This thin conception of democracy, that both sides of the argument over prisoner enfranchisement take for granted, is consistent with contemporary political life in Europe. It is, however, a counterfeit of democracy in the sense of a society in which the people collectively govern themselves because they are the authors of the laws that they obey. Retaining the ban on prisoners' voting is the only decision that will not further institutionalize this counterfeit in the UK's political life.

I will not, therefore, be holding up one straw man that regularly gets knocked down by opponents of the ban. The argument made here is not that prisoners ought to suffer 'civic death' or anything like it. Prisoners have rights, and any

${ }^{1}$ I have been unable to find any argument in favour of the UK's ban or against the Hirst judgment in the recent academic literature on the subject. In February 2011 the House of Commons voted overwhelmingly against reforming the ban. 
society that takes collective self-government seriously will take a very close interest in protecting prisoners' rights and improving their welfare. ${ }^{2}$ Many aspects of the UK's current penal policy would shame a democracy that took collective selfgovernment seriously. The ban on prisoners voting is, however, not one of them.

\section{THE GOVERNMENT'S ARGUMENT IN HIRST}

The UK government argued that, while the ban was an interference with prisoners' rights, it was not a violation of the Convention because it was necessary in a democratic society in pursuit of the legitimate aims of 'preventing crime and punishing offenders and enhancing civic responsibility and respect for the rule of law'. The ban served these aims 'by depriving those who had breached the basic rules of society of the right to have a say in the way such rules were made for the duration of their sentence'. ${ }^{3}$ The government added that 'Convicted prisoners had breached the social contract and so could be regarded as (temporarily) forfeiting the right to take part in the government of the country.'4 Finally, it argued that the limitation on prisoners' right to vote was proportional since it lasted only for as long as they were imprisoned. ${ }^{5}$

The problem with this argument is that the final claim that disenfranchisement is proportional because limited to the period of imprisonment is undermined by the preceding argument that prisoners have forfeited their political rights because they have breached the social contract. To argue that those who breach the 'basic rules of society' lose the right to vote is to claim too much. Assuming that prohibitions on assaults, acts of vandalism and thefts of personal property are among the basic rules of a democratic society, then these basic rules are broken by all those who commit these offences, including many who will not go to prison. According to the government these offenders too have forfeited the right to take part in the government of the country. The government's argument therefore misses its target. It needs to justify the disenfranchisement of prisoners, not of all offenders.

We will return to this below, but first we should understand that the government's argument, although it may appear to be democratic - only those who play by the rules get to make them - betrays a thin conception of democracy, one in which citizens get to vote but they are not addressed by the penal law as if they were its ultimate authors. To see why disenfranchising all offenders makes it impossible to maintain a penal law that respects the authority of citizens as the

\footnotetext{
${ }^{2}$ For more of this argument, see P Ramsay 'Voters Should not be in Prison: The Rights of Prisoners in a Democracy' (2013) 16(3) Critical Review of International Social and Political Philosophy (forthcoming).

${ }^{3}$ Hirst v UK 2005, para [50].

${ }^{4}$ Ibid.

${ }^{5}$ Ibid para [51].
} 
ultimate source of legal obligations, we have first to understand why democracies are able to punish citizens at all.

In a democracy, citizens are formally equal as the ultimate source of legitimate government action under law. Any punishment is a deprivation of their rights by the state, and the state would fail to treat citizens as equal in their formal authority if it were able to deprive citizens of their rights without their prior authorization. Explicit authorization of punishment by the person punished would be rare indeed. Nevertheless, such authorization is implicit to the extent that an offender actively denies another's citizenship rights by breaching the basic rules of society, since to that extent the offender denies citizenship rights as such, including her own. It is important to recognize that the most familiar and longstanding offences involve just such a denial of citizenship. An offender who deliberately and coercively attacks another's person or property, by making a claim of natural right in the Hobbesian sense, denies the other's personhood, which is to say, the other's capacity for self-government. ${ }^{6}$ Homicide, assault, sexual assault, criminal damage, thefts of personal property, for example, are, on this account, all violations of personhood. In so far as a political regime takes collective self-government seriously, citizenship must presuppose the personhood of citizens, because personhood is the characteristic that lends individuals the capacity to partake in collective self-rule. ${ }^{7}$ The offender's denial of personhood represented by the offence is, therefore, also a denial of democratic citizenship rights in so far as it treats the presuppositions of citizenship as of no account next to the satisfaction of the offender's own appetites and desires. ${ }^{8}$

To the extent that the commission of an offence is, therefore, an active denial of citizenship, and only to that extent, the offender authorizes the state to act on her own denial of citizenship and deprive her of her citizenship rights in the form of punishment. 9 This democratic authorization of punishments entails a system of

6 'Deliberately' implies that the offence includes some fault requirement - that the prosecutor must prove that the defendant was at fault for the attack.

7 A democracy will also need to uphold citizenship rights that go beyond interests in personhood, and uphold them in the form of 'basic rules of society' by means of penal regulation. But this is not a fundamental consideration in the present context. For more on this, see Ramsay n 2 above.

8 Providing imprisonable offences require proof of a fault element, there is, therefore, no need to prove separately that the offender intended to repudiate the social contract (contra S Brenner and NJ Caste 'Granting the Suffrage to Felons in Prison' (2003) 34(2) Journal of Social Philosophy 228, 239). Christopher Bennett also recognizes that offending characteristically involves 'a failure to respect the basic terms of the civic relationship', see C Bennett, 'Penal Disenfranchisement', Paper for the Democracy and Criminal Justice Project (available at http://www.democracyandcriminaljustice.org/ penal disenfranchisement paper). But Bennett overlooks the essential connection between political rights and civil liberties that I argue for below and so misreads disenfranchisement as an extra retributive punishment, see text at $\mathrm{n} 38$ below.

${ }_{9}$ Of course, it can be argued that it is unjust to punish many individuals who fail to obey the basic rules of a society if the distribution of wealth and opportunity in that society systematically disadvantages those who often end up before the criminal courts. But this is an argument about the justice of the penal law as such. Any society that aspired to collective self-government would address such issues as a matter of urgency, but it would not do so by undermining the basis of democratic self-government in the way that, as I will argue below, prisoner enfranchisement does. It is an insult to both democracy and prisoners to 
ordinally proportionate penalties: the more serious the offence, the more serious the denial of citizenship rights, the more serious the penalty - and vice versa. ${ }^{10}$ Only with such ordinally proportionate punishments are citizens coerced as equals because only such proportionate penal deprivation of rights can be regarded as implicitly authorized by the offender who suffers them, and therefore within the democratic authority of the state to impose.

If all offenders are disenfranchised, however, the system of ordinally proportionate punishments is anchored at such a high level on the cardinal scale that it is inconsistent with the democratic presupposition that offenders are persons. In a democracy that takes collective self-government seriously, the right to vote is the 'right of rights'. ${ }^{11}$ Removing that right is therefore a very serious punishment. Disenfranchising minor offenders would mean that the lowest point on the scale of punishments is a very serious deprivation of rights. An ordinally proportionate system of punishment anchored at this point would have to impose very severe punishments on more serious offenders if it was to treat citizens equally and distribute punishments consistently with the equal authority of citizens. The result would be that more serious offenders would routinely have to endure very long terms of imprisonment. ${ }^{12}$ This would amount to society effectively giving up on these offenders. The incapacitating severity of the penal system would fail to treat many prisoners as persons, potential authors of their own lives, in a way that they have not authorized. Efforts at rehabilitation would become pointless among the many offenders who would not leave prison for decades. A democracy that routinely imprisoned offenders for large portions of their lives on the basis of the (albeit serious) errors they had made would violate its own premise that its citizens, because they are persons, are capable of self-rule (notwithstanding the many errors of all sorts that persons and democratic citizens will doubtless make). The penal law would cease to address citizens with threats of punishment that took them seriously as persons and, therefore, as the authors of the laws that they were required to obey. Instead the law would merely terrorize the citizenry. ${ }^{13}$

In other words, the underlying political content of the government's overly broad and speciously democratic argument for the disenfranchisement of prisoners is the familiar 'tough on crime' message that has been a staple of

argue that prisoners should have the vote because the loss of civil liberty that results from their imprisonment is unjustified. It is the prisoners' loss of civil liberty that we should be addressing (see also n 40 below).

${ }^{10}$ It entails a good deal more than this as well, including, in one form or another, adequate guaranteed access to the goods necessary to live the life of a citizen (see Ramsay, $\mathrm{n} 2$ above).

11 William Cobbett cited in J Waldron, 'Participation: The Right of Rights' (1998) Proceedings of the Aristotelian Society 307.

12 Note that disenfranchising only prisoners does not escalate ordinally proportionate sentences in this way. Once the threshold of imprisonment is passed the loss of the vote persists in exact proportion to the loss of liberty. The UK government asserted this point in Hirst but was unable to explain why prisoners should lose the right to vote at all when other offenders did not. See text after $\mathrm{n} 14$ below.

${ }^{13}$ Compare A von Hirsch, 'Proportionate Sentences: A Desert Perspective' in A von Hirsch, A Ashworth and J Roberts (eds), Principled Sentencing: Readings on Theory and Policy (Hart, 2009) 120-21. 
contemporary political life. The government's argument, if seen through on its own terms, would discount the equality of citizens by threatening them with a penal law that was inconsistent with their ultimate authority. Moreover, this argument entirely fails to explain why the disenfranchisement of imprisoned offenders is necessary in a democratic society. In Hirst the court ruled that 'the principle of proportionality requires a discernible and sufficient link between the sanction and the conduct and circumstances of the individual concerned'. ${ }^{14}$ The government's argument demonstrates a discernible link between the disenfranchisement of prisoners and enhancing civic responsibility and respect for the rule of law - prisoners have broken the basic rules of society. But it has not shown a sufficient link so as to explain why it is necessary that only prisoners should be disenfranchised, since many unimprisoned offenders have also broken the basic rules. Banning only imprisoned offenders from voting implies that it is offence seriousness that is the reason that provides the link, but offers no explanation as to why seriousness sufficient for imprisonment should mark the point at which offenders lose the vote.

\section{THE HIRSTJUDGMENT AND AFTER}

The majority of Strasbourg judges in the Hirst court concluded from this failing in the UK's argument that disenfranchising all prisoners must be an arbitrary interference in the right. In their opinion, the UK's ban:

strips of their Convention right to vote a significant category of persons and it does so in a way which is indiscriminate. It imposes a blanket restriction on all convicted prisoners in prison. It applies automatically to such prisoners, irrespective of the length of their sentence and irrespective of the nature or gravity of their offence and their individual circumstances. ${ }^{15}$

As a consequence, the UK's ban fell 'outside any acceptable margin of appreciation' that might be allowed to a national government in pursuing the legitimate aims of ensuring civic responsibility and respect for the rule of law, ${ }^{16}$ and it was, therefore, disproportionate and a violation of the Convention.

It should be noted that, just as the government's argument failed to offer a reason why the prohibition on prisoners (as opposed to offenders) voting was necessary in a democratic society, so the Grand Chamber's opinion offers no refutation of that proposition. The majority opinion merely states, correctly, that

${ }^{14}$ Hirst, $\mathrm{n} 3$ above, para [71].

15 Ibid, para [82].

${ }^{16}$ Ibid. 
the ban fails to discriminate among prisoners. The issue at stake, however, is whether it is necessary in a democratic society to discriminate between prisoners as a group and all other citizens (including convicted offenders who have not been imprisoned). Given the insufficiency of the reasons offered by the government, the Hirst court simply assumes that this is not necessary without ever addressing the question directly.

Hirst then is an ambiguous judgment. It declares the UK ban to be disproportionate without indicating what sort of limitation on voting rights would be proportionate. In the subsequent case of Frodl v Austria, the Strasbourg court interpreted Hirst's objection to a 'blanket' ban as extending to Austria's rules disenfranchising prisoners convicted of offences of intention and serving more than one year. The court concluded that disenfranchisement could only ever be exceptional, and, therefore, could only ever be proportionately imposed by a judge, on a case-by-case basis, rather than by any legislative rule. Moreover, even this would only be possible where there was 'a link between the offence committed and issues relating to elections and democratic institutions'. ${ }^{17}$

The reason for this broad interpretation of Hirst derived from a principle reiterated by the Frodl court: that 'prisoners in general continue to enjoy all the fundamental rights and freedoms guaranteed under the Convention save for the right to liberty'.18 Any general rule disenfranchising all prisoners or some prisoners on grounds of seriousness would necessarily violate that principle in its generality. The purpose of Frodl's narrowly specified criteria was 'to establish disenfranchisement as an exception even in the case of convicted prisoners', an exception that could be accounted for by 'specific reasoning given in an individual decision explaining why in the circumstances of the specific case disenfranchisement was necessary'. ${ }^{19}$

The Frodl decision, however, implied the need for a very radical reform of the UK's law and made political compromise between Strasbourg and an intransigent House of Commons very difficult indeed. As a consequence, in the subsequent case of Scoppola v Italy, the Grand Chamber took advantage of Hirst's ambiguity to retreat from the broad interpretation in Frodl. ${ }^{20}$ It upheld Italian rules that imposed a five-year voting ban on prisoners serving more than three years, and a lifetime voting ban on prisoners serving more than five years. Again the court did not say explicitly that this rule was proportionate. Against the Frodl ruling, the Scoppola court pointed out that the Hirst judgment nowhere mentions that judicial intervention is essential. ${ }^{21}$ It ruled that the Italian ban took sufficient account of the individual circumstances and gravity of the offence so as to lack the 'general, automatic and indiscriminate character' of the UK's ban, and, therefore, fell within

\footnotetext{
17 Frodl v Austria, 20201/04 (2010), para [34].

18 Ibid [25].

${ }^{19}$ Ibid para [35].

20 Scoppola v Italy (No 3) 126/05 (2012). Life prisoners can apply to have the ban revoked on the grounds that they have reformed.

${ }^{21}$ Ibid, para [99].
} 
the 'margin of appreciation' given to states in judging whether or not a restriction on the right is proportionate and necessary in a democratic society. ${ }^{22}$

By applying the margin of appreciation doctrine, the Scoppola court avoided (or evaded) giving any explicit positive explanation of its own as to why a ban on prisoners serving over three years might be necessary and proportionate when the UK's ban could not be. As Judge Bjorgvinsson pointed out in his dissent in Scoppola, it is still not clear, therefore, why the Italian rules fall within the margin of appreciation if the British rules do not. Without some positive explanation as to their proportionality, the Italian legislation may be 'more lenient' but it appears to be 'just as blunt as the legislation in the United Kingdom'.23 Moreover, as one commentator observed:

there is no principle whatsoever in saying that a law prescribing that no prisoner may vote while in prison is arbitrary, while a law prescribing that prisoners sentenced to five years or more in prison can be banned from voting for life and those sentenced to three years can get a five-year voting ban, is not arbitrary. If, in other words, the gravity of the crime, and accordingly of the sentence, is sufficient in and of itself to justify a voting ban, regardless of the nature of the crime, then why can't the same reasoning be extended to a prison sentence as such, as opposed to say a fine or some other form of punishment. ${ }^{24}$

The position we are left in is one in which the disenfranchisement of prisoners serving more than three years will not violate their rights under the ECHR, while disenfranchisement of all prisoners will, but without any apparent principle underlying these politically significant rulings. ${ }^{25}$ The unprincipled pragmatism of the Scoppola judgment has been widely noted and as widely welcomed for providing some basis for a face-saving compromise of the embarrassing political stand-off between Westminster and Strasbourg. ${ }^{26}$

The Frodl judgment is certainly a more principled interpretation of Hirst. It derives a narrow set of exceptional disenfranchisement rules from a general

22 Ibid, [106]-[108].

${ }^{23}$ See Dissenting Judgement, ibid.

${ }^{24}$ M Milanovic, 'Prisoner Voting and Strategic Judging', European Journal of International Law Blog, 22 May 2012 (available at http://www.ejiltalk.org/prisoner-voting-and-strategic-judging/).

25 One 'principle' that just might reconcile Hirst and Scoppola is found in Judge Caflisch's Concurring Opinion in Hirst. He argues that we should not assume that all prisoners have broken the social contract, disenfranchising them will not therefore serve the legitimate aim of inculcating respect for it. If we assume that such prisoners are generally serving shorter terms then this might rationalize the Scoppola compromise. It should be plain from the preceding argument here, however, that no regime that took collective self-government seriously would have the authority to imprison those who had not violated its basic rules. I have argued elsewhere that Judge Caflisch's suggestion would scandalize a political order that took self-government seriously, though it has passed almost without comment in our own (see Ramsay n 2 above).

${ }^{26}$ See, for example, Milanovic's concluding remarks in the article cited at n 24 above. 
principle that prisoners continue to enjoy Convention rights. However, from the point of view of democracy as collective self-government, the principled position in Frodl is no less subversive than the Scoppola farrago.

\section{TAKING THE CRACY OUT OF DEMOCRACY}

The Frodl judgment argues that prisoners should retain their right to vote because it is a fundamental right protected by the ECHR, and the only Convention right that is lost by prisoners who are lawfully imprisoned is the 'right to liberty'. Exceptions to this fundamental right should be just that - truly exceptional. This sounds very principled and democratic - ensuring universal suffrage in the representative political process. But the democratic commitment of this principled Strasbourg jurisprudence is as specious as that of the UK government, albeit for a different reason: the Strasbourg principle entirely discounts the essential connection between the right to liberty that prisoners have lost and collective selfgovernment.

The 'right to liberty' is the precondition for exercising several of the other civil liberties: the right to move, to associate and assemble for example. It is wholly artificial to claim that a prisoner enjoys these rights. Moreover, prisoners may retain a formal right to free expression, but their actual ability to speak to others is hugely circumscribed by their loss of liberty. ${ }^{27}$ These civil liberties (that are taken away from prisoners) are a necessary condition of collective self-government by means of representation. ${ }^{28}$ Without the freedom to innovate, communicate, debate and organize around political ideas there is no possibility of the people collectively ruling themselves by being the true authors of the laws that they will obey. If the executive controls these aspects of a person's life then, regardless of whether or not that person gets to choose between different political products, she is not in ultimate control of the terms on which she contributes to their creation or the terms on which she participates in political deliberation, and she is not, therefore, part of a process of collective self-rule. There is no group of people whose liberties are more directly controlled by executive discretion than convicted prisoners.

By overlooking this essential connection between civil liberty and selfgovernment the European Court of Human Rights, in all three judgments, constructs the vote as nothing more than a choice between different political

27 Prisoners' Article 10 rights are also limited by the needs of prison discipline and order, see $\mathrm{R} v$ Secretary of State for the Home Department exp Simms and O'Brien [2000] 2 AC 115. See also PSO 4400 which sets out the restrictions on prisoners' access to the media by telephone, and, on prisoners' rights to correspondence, Nilsen v Governor of HMP Full Sutton [2004] EWCA Civ 1540.

28 There is an overlapping consensus on the essential connections between civil liberty and democratic representation (see, for example, R Dahl, Democracy and Its Critics (Yale University Press, 1989) 170 However, as I shall argue, the more minimal the conception of democracy, the narrower the scope of the liberties required (see text after $\mathrm{n} 35$ below). 
products that can be made by any person, including prisoners. But where democracy is a regime in which citizens obey laws that they have given to themselves, the vote is a decisive moment (literally) in the wider popular deliberation as to what the laws ought to be. It is not possible to imagine that the political decisions made by representative institutions are in any way the decisions of the people unless all citizens are formally equal and formally independent of the executive. By virtue of their imprisonment, prisoners are neither of these.

Prison officials may object to this line of argument. They will justifiably say that they encourage political participation by prisoners. Indeed the prison governors association and many other organisations involved in the rehabilitation of prisoners support the enfranchisement of prisoners, and not without reason. They supported the argument, put to the Hirst court by two third party interveners, that the rehabilitation of prisoners and their reintegration into normal social life is not assisted by disenfranchisement, and would be assisted by reenfranchisement. ${ }^{29}$ Together with the idea that the vote is a universal right, this is the most important argument made by those who support reform of the ban. And it too exemplifies the thin idea of democracy in which citizens get to vote for representatives but they are not taken seriously as the true authors of the laws that they are required to obey.

The reformers' argument is that prisoners' rehabilitation will be assisted by their inclusion in the electoral process: if the state treats prisoners as citizens by allowing them to participate then it is more likely that prisoners will on release take their own civic obligations seriously, and vice versa. The problem with the argument is that it assumes that because we permit prisoners to vote we therefore treat them as citizens of a democracy. ${ }^{30}$ It assumes that democratic citizenship is a matter of being able to choose between different candidates to represent us in the legislature. From the standpoint of a regime of collective self-government, we do not treat prisoners as citizens merely because we allow them to vote, for we do not allow them to deliberate and organize politically in the way that citizens of a democracy must be allowed to.

No doubt many prisoner governors and educators will insist that they would encourage prisoners to do more than just vote; they would encourage them to read about and discuss the political issues of the day before deciding how they should cast their vote. After all, this too is part of taking their civic rights and responsibilities seriously. Perhaps prison officials would even extend this rehabilitative impulse to allowing imprisoned sympathisers of the British National Party or radical Islamism to express their opinions too. Governors and prison officers might even forswear taking any account of who holds which opinions in their subsequent administration of the prisoners' lives. But even governors that

${ }^{29}$ See Hirst $v$ UK, para [53].

30 See for example, V Stern, 'Prisoners as Citizens: A Comparative View' (2002) 49 Probation Journal 130, 135; D Cheney, 'Prisoners as Citizens in a Democracy' (2008) 47(2) Howard Journal 134; S Easton, Prisoners Rights: Principles and Practices (Routledge, 2011) 211-39. 
were this liberal about political deliberation would nevertheless be failing to treat their prisoners as citizens of a state that takes the aim of collective selfgovernment seriously.

Even the most liberal prison governor would not allow voting prisoners to go wherever the prisoners wanted to, whenever they wanted to, in order to exchange opinions with whomsoever they wanted to, about any subject that they wished to discuss, and to associate and assemble with others of their choosing in order to organize and promote those opinions. It would be dereliction of a governor's duty if she were to extend these basic liberties to her prisoners as of right. In other words, giving prisoners the vote, on the grounds of their citizenship, logically eliminates the civil liberties from democratic citizenship.

It might be true that giving prisoners the vote is in fact an effective means of rehabilitating them by encouraging respect for society's norms. But this would, in the same moment, be an admission that those norms do not include the selfgovernment of the people. If a court or parliament offers prisoners the vote on the grounds that they will come to understand their civic responsibilities better, any suggestion that those civic responsibilities include a duty to contribute to collective self-government would be a false representation, for self-government is precisely the capacity that prisoners are unable to exercise by virtue of their formal inequality that is brought about by being deprived of civil liberties and being rendered formally dependent on the executive. Opponents of the ban are wrong to claim that 'prisoner disenfranchisement is inconsistent with the notion of political equality that underlies ideas about the right to vote'. ${ }^{31}$ On the contrary, prisoner disenfranchisement, by ensuring that the political playing field is formally equal and free of executive control, is one of the institutional forms of political equality.

Reforming the Representation of the People Act to allow prisoners to vote would be a contribution to counterfeiting democracy, extending the outward form of democratic government as a cover for the absence of the political substance of democracy - the self-government of the people.

The rehabilitation of offenders is of course an important commitment of a truly democratic penal policy because, as we have seen above, much offending amounts, among other things, to an implicit repudiation by the offender of the possibility of collective self-government. Promoting democratic self-government, therefore, requires the penal system to seek to rehabilitate offenders so that they too may join the collective process of self-government. In the reformers' argument, however, this relation between democracy and rehabilitation is stood on its head. Rather than rehabilitation being understood as a means to the end of democratic self-government, the reformers' present the vote - the democrat's 'right of rights' - as a means to the end of the rehabilitation of offenders. The connection between rehabilitation and democratic self-government is eliminated along with the connection between civil liberties and democratic self-rule.

${ }^{31}$ H Lardy, 'Prisoner Disenfranchisement: Constitutional Rights and Wrongs' (2002) Public Law 524, 545. 
Both the reformers' argument that some or all convicted prisoners should have the right to vote and the judgments of the Grand Chamber of the European Court of Human Rights serve to eliminate the independence of political deliberation from executive control as an essential component of democratic citizenship. Theirs are arguments that are consistent with the view that democratic citizenship is membership in a polity in which people make a choice between whatever political options happen to be available, but not with the view that democratic citizenship is membership in a polity in which people obey laws they have given to themselves. If democratic citizenship is the former, and democracy is no more than a process by which one or another section of a political elite gains the electorate's consent to rule, then prisoners can be citizens as much as the next person. Indeed, the underlying logic of this argument is that citizens do not need any civil liberty beyond the freedom to inspect the legally permissible range of political products and to debate their merits sufficiently to allow them to make a choice - and this is where the real danger to democracy lies.

\section{FAKING IT}

The transformation of electorates into passive consumers choosing among different political products in a narrowly defined and highly manipulated political market place is a well-established trend in Western society. The Hirst judgment's assumptions, and the wider argument for prisoners voting rights, are complicit in this trend, one that has been described as 'post-democracy'. ${ }^{32}$ The connection between the post-democratic trend and the rise of neoliberal market imperatives is well understood. ${ }^{33}$ Less well understood is the contribution of human rights to post-democracy.

The term post-democracy may be misleading in some respects, but it is apposite in so far as it precisely captures one quality of our political arrangements, a quality exemplified by the argument over prisoner enfranchisement. Postdemocratic regimes are not self-consciously anti-democratic. On the contrary, their political elites have no alternative to the language of democratic legitimacy. They profess great concern for the formalities of democratic politics. This is because they are states that persist after an earlier more active political engagement on the part of the citizenry has declined, but without the emergence of any alternative form of political legitimacy to democracy. Post-democratic regimes are, therefore, required to bluff: organizing themselves through elections and parties, and making much of participation and democratization, despite the decay of the

32 J Habermas, Guardian 10 November 2011; C Crouch, Post-Democracy (Polity 2004; J Ranciere, Disagreement (University of Minnesota Press, 1995).

33 See Crouch and Ranciere, ibid. The connection between neoliberalism and the kind of punitive excess found in the UK government's assumptions in Hirst has been exhaustively discussed in the literature. 
substance of democratic politics (that is, of the practice of citizens endeavouring to rule themselves).

Post-democratic regimes are able to pull off this bluff largely because of the disappearance of the belief that representative government can be anything more than a matter of one or other section of the political elite gaining the votes of citizen-consumers in the political market place. Conservatives have long promoted this minimalist view of representative government. ${ }^{34}$ The argument that prisoners have a human right to vote indicates the prevalence of this minimalist view among liberals and human rights advocates too. Indeed, the rise of human rights talk on the political left has been the counterpart of the waning of the social-democratic belief in popular sovereignty. We can understand our 'post-democracy' as the moment in which this minimalist conception of representative democracy has, for the present at least, entirely marginalised the connection between political representation and the self-government of the people. ${ }^{35}$

In the minimalist conception of representative government, the citizen is a political consumer. Her civil liberties need to be protected only in so far as it is necessary to facilitate a political market place of some sort. Civil liberties are much less important in the minimalist conception of democracy than they are to democracy as collective self-government. It is perfectly possible to make a choice between political alternatives while heavily circumscribing the scope of civil liberties. As the political influence of ordinary citizens is reduced to a passive choice between narrowly differentiated political brands, it is perhaps no surprise to discover the UK government deploying a penal argument for prisoner disenfranchisement that implicitly discounts the ultimate political authority of citizens. It is more disturbing to find the government's legal and academic critics implicitly discounting the civil liberties that those citizens need if they are collectively to be the authors of the law. It is in this fundamental sense that, on all sides, the contemporary political order is faking democracy.

As a practical matter, the enfranchisement of 80,000 or so convicted prisoners will make little difference to election results. It is not the practicalities of prisoner enfranchisement that are an obstacle to democracy. It is the principle. Some compromise of democratic principles in the cause of rehabilitation might be less of a problem if we lived in a political culture that was, in general, jealous of its civil liberties because it was the political culture of a population energetically pursuing self-government. But we are very far from that political culture. ${ }^{36}$ For

${ }^{34}$ See, for example, J Schumpeter, Capitalism, Socialism and Democracy (George Allen \& Unwin, 1943) 269.

35 The dominant tendency within political theory has always been skeptical about this connection, tending to regard so-called 'direct democracy' as the condition of achieving popular sovereignty and representation as a way of frustrating it. A minority has nevertheless defended representation on these grounds. For an account see N Urbinati, Representative Democracy: Principles and Genealogy (University of Chicago Press, 2006) 3-8. For contemporary theories of representation as the means to self-government see Urbinati, ibid; D Plotke, 'Representation is Democracy' (1997) 4(1) Constellations 27; P Ramsay 'Democratic Limits to Preventive Criminal Law' in A Ashworth, L Zedner and P Tomlin (eds), Prevention and the Limits of the Criminal Law (Oxford University Press, 2013).

${ }^{36}$ For a summary, see KD Ewing, Bonfire of the Liberties (Oxford University Press, 2010) Chs 2-7. 
anyone who takes the prospect of popular self-government seriously, it is vital not to compromise its principles at the present time.

The misleading aspect of the term 'post-democracy' is that it puts democracy in the past, as if we have been there, done that and moved on. But true political self-determination was not accomplished in the past, and the potential for political freedom remains for human beings to achieve in the future. Of course, to anyone who does not take that prospect seriously the principles of self-government will be of much less interest.

Notwithstanding the UK government's own undemocratic arguments for it, the ban on prisoners voting is an institutional form of the democratic principle that those who lack civil liberties cannot rule themselves politically. Imprisonment is the point at which an offender's denial of democratic citizenship rights is serious enough that it is necessary in a democracy to deprive her of the vote, precisely because her denial of citizenship by offending is serious enough to deprive her of her liberty. This deprivation of political rights is proportionate because it lasts no longer than her imprisonment. ${ }^{37}$ From the point of view of collective selfgovernment, disenfranchisement is not an extra punishment in addition to imprisonment, but is rather a loss of political rights that is entailed by the deprivation of civil liberties. ${ }^{38}$ Disenfranchisement on this basis does not treat the vote as 'revocable privilege' to be removed from those who lack 'moral worth'. ${ }^{39}$ The prisoners have themselves repudiated their democratic citizenship rights by the implicit denial of citizenship entailed in their offence. 40 Nor does the suspension of prisoners' voting rights for the period of their incarceration imply that they should be deprived of all rights or endure 'civic death'. There are very good reasons why all kinds of people who lack full citizenship status enjoy many rights in a democracy without enjoying the right to vote, and prisoners are no exception to this. ${ }^{41}$

37 This argument rules out US-style felon disenfranchisement after release.

${ }^{38}$ It is only when civil liberty and political freedom are divorced from each other that disenfranchisement appears as an extra punishment that is hard to justify on proportionality grounds. See, for example, the discussions of disenfranchisement as a retributive response in Bennett, n 8 above, and in Easton, n 30 above.

39 Contra S Easton, 'The Prisoner's Right to Vote and Civic Responsibility: Reaffirming the Social Contract?' (2009) 56 Probation Journal 226-29.

40 Of course this is true only in so far as imprisonment is available for a restricted range of offences. In practice many people are imprisoned who have not done enough to amount to a renunciation of democratic citizenship - for possession offences to take an obvious example. (See Ramsay n 2 and n 35 above.) Moreover there is some evidence of racial discrimination in sentencing in the UK so that some non-white offenders serve time in prison when a white offender would not for an offence of similar seriousness. But such offenders should not be in prison at all. Enfranchising them would merely add insult to injury and tend to legitimize the far more serious wrongful violation of their civil liberty achieved by their imprisonment (contra Cheney, n 30 above).

${ }^{41}$ In a democracy non-citizens (foreigners and children, for example) enjoy the protections of the criminal law, rights to legal representation, for example, because they are persons or potential persons and, therefore, potential citizens. A democracy would also uphold welfare rights for prisoners and maintain the right of all citizens to dispute judicial decisions politically by nominating and voting for prisoners in elections. See also Ramsay n 2 above. 
Complying with the Hirst judgment, on the other hand, will further institutionalize the counterfeit conception of democracy in which citizens get to vote, but voters are not imagined as self-governing citizens who obey laws that they have truly given to themselves. Worse, this counterfeit democracy would be institutionalized in the name of democratization, of human rights and of social inclusion, with the appearance, at least, of majority support among liberal and leftleaning penal reformers, experts and academics. It should come as no surprise to anybody that our exhausted political class dresses up its elitist arguments in fake democratic guise. It is much more problematic when the arguments of the critics, the reformers, activists, lawyers and intellectuals also present a fake version of democracy. If the critics' version is left unchallenged, the idea of collective selfgovernment may be erased from our understanding of what democracy means. That would be a severe setback to the interests of all those who currently lack real power and authority, imprisoned offenders included. 